\title{
Cassava Processor's Awareness of Improved Processing Technologies in Oyo State
}

\author{
Olayemi, O.O. ${ }^{1}$; Ajanaku, A.O; Ewebiyi, I.O. ${ }^{2}$
}

\author{
${ }^{1}$ Department of Agricultural Extension and Management, Federal College of Forestry, Ibadan, Oyo State. P.M.B.5087 \\ bodecrespo1@yahoo.co.uk 08054035443, aanikkyd24@gmail.com 07035071223 \\ ${ }^{2}$ Department of Agricultural Science (Agricultural Extension and Rural development Unit), Tai-Solarin University of Education, \\ Ijagun, Ijebu-Ode, Ogun State. tayoewebiyi@yahoo.com 08055210068
}

\begin{abstract}
The cassava production is most carried out by smallholder farmers in the rural areas using low-level production techniques which have left them with production of cassava tubers without much value addition. Therefore cassava processors' awareness of improved processing technologies in Oyo State was investigated.

Simple random approach was employed through questionnaire and interviews to collect information from 176 Cassava processors. Descriptive and inferential statistics such as frequency counts, percentages, mean, Chisquare were used in data analysis at 0.05 level of significance.

Results of analysis revealed that majority (77.2\%) of the respondents fell within the age range of 21 years to 50 years with mean age of 41.23 and greater population of females (75.6\%) than the males $(24.4 \%)$. Over $45.5 \%$ had secondary and below as their educational qualification with most (75.6\%) married, with fairly large household size 4-6
\end{abstract} persons.

The respondents' level of awareness of improved processing technologies among most need respondents low $(54.5 \%)$ and this may accounted for low level of utilization of improved processing technologies among majority (56.8\%) of the respondents. Chi-square analysis revealed that, among socio-economic characteristics of the respondents, religion $\left(x^{2}=6.805, p=0.033\right)$, educational qualification $\left(x^{2}=10.572, p=0.032\right)$, mode of processing $(x$ $\left.{ }^{2}=14.015, p=0.001\right)$ and mode of Labour $\left(x^{2}=11.960\right.$, $p=0.003)$ were significantly related to respondents' awareness of improved processing technologies. The result revealed clearly that respondents' awareness of improved processing technologies does not depend on marital status, sex, household size and experience.

It is therefore recommended that Government and NGO's should encourage extension agents by giving them motivation as at when due to improve their services of dissemination of information to the cassava processors on awareness of improved processing technologies toward enhancing higher productivity, income and better standard of living of the respondents in the study area.

Keywords- Cassava processors, awareness, Improved processing technologies.

\section{INTRODUCTION}

In the area of cassava production, the recent Agricultural Transformation Programme of the Federal Government which has facilitated the establishment of Cassava processing plants, exportation of Cas sava chips to countries like China has led to increase in the interest of the rural famers including women to increase their level of Cassava production and processing. In the domestic parlance the rural women processing cassava into various products such as cassava flour, chips, and starch among other products.

In Nigeria, women cassava utilizers constitute more than $60 \%$ of the adult population resident in the rural areas (Odebode, 1997). However, their traditional contribution to agricultural production has been rendered inefficient by the crude and inappropriate form of agricultural technologies frequently used (Olawoye, 1988), the result is a relatively low agricultural productivity, which is inversely proportional to the enormous labour intensive input. It is against this backdrop that this research investigated the extent of the cassava processors' awareness of improved processing technologies in Oyo State.

Specific objectives

The specific objectives of this study include to:

i. Identify socio-economic characteristics of the cassava processors in Oyo state.

ii. Determine the level of awareness of improved processing technology by cassava processors in Oyo State.

iii. Find out attitude of respondents towards utilization of improved processing technology in the study area. 
Hypothesis of the study

The hypothesis stated in the null form is tested:

Ho1 - There is no significant relationship between awareness of the respondents and their utilization of improved processing technology in the study area.

\section{MATERIALS AND METHODS}

The study was carried out in Oyo state, which is one of the six states in south west Nigeria. The economy of the state is based on the agriculture and the major occupation of the rural people is farming. The climate in the state favour the cultivation of crops like maize, yam, cassava, millet, rice, plantains, cocoa, oil-palm, cashew etc. They engage in other activities such as transport operation, blacksmithing, tailoring, and carpentry and so on. The state is homogenous and comprises the Oyos, the Ibadans and the Ibarapas, all belonging to the Yoruba family and speaking the same Yoruba language. People within and outside the country trade and settle in the urban areas. The capital, Ibadan is reputed to be the largest city in African, south of the sahara.

\section{Sampling Procedure and Sample size}

A Multi-stage sampling procedure was used to select respondents for the study. Random selection of $50 \%$ of the two ADP zones (Ogbomoso and Ibadan/Ibarapa), Purposive sampling Technique was used to select Local Government and Communities that are predominantly noted for cassava production and processing from the selected two zones: Ogbomoso South Local government ( Ogbomoso zone) and Ibarapa East Local government (Ibadan/Ibarapa zone). List of registered cassava processors in selected communities was collected from the Department of Agric. and Health at the Local Government Headquarters in Arowomole and Eruwa respectively. 50\% of registered Cassava Processors in selected communities was randomly selected and this gives a total of one hundred and seventy six (176) respondents that was used for the study.

\section{Analysis of data}

Data Collected were subjected to descriptive and inferential Statistical analysis using Statistical Package for the Social Sciences (SPSS). Descriptive statistical tools used included frequency counts, mean and percentage while inferential statistical used is Chi-square.

\section{RESULTS AND DISCUSSION}

Socio-economic characteristics of respondents

The mean age of all the respondents was 41.23. This implies that most of the respondents are in their active ages and this may urge them favourably to utilize improved processing technologies for their cas sava processing.
This finding is in line with that of Akinbile (2007) and Adedeji et al (2013) who reported a mean age of 41.42 with age-range (20-50years) that constitutes the active workforce of the population.

Results of analysis on respondents' sex in Table 1 revealed that $24.4 \%$ are males while $75.6 \%$ were females in the study area. This implies that females are more predominant in cassava processing than males in the study area. Results further showed that most $60.8 \%$ of the respondents were Christians, 36.4\% were Muslim and few ones 2.8\% were traditional believer. Religion believe is one of the major identities of Nigerians. Oyesola and Ademola (2011) asserted that religion institution can assist in making information available most especially in rural areas on awareness and utilization of improved processing technologies among cassava processors. This finding is in agreement with the work of Torimiro et al., (2006) that majority $(70.9 \%)$ of the rural dwellers are Christians.

Results in Table 1 also revealed that most respondents (75.6\%) were married. This implies that marriage institution is still highly esteemed in our society because it is evidence of being responsible. This result is also in tandem with report of Ewebiyi and Arimi (2013) who submitted that marriage institution plays a key role in the livelihood of rural dwellers. The results further showed that most (58.0\%) of the respondents had four to six persons household size. This implies that the household size among the rural dwellers is fairly large because most of the respondents rely on family labor. This result collaborates with findings of Oluwatayo and Aliyu (2007) that the household size among rural farm families is usually large. The results also revealed that majority of the respondents $(33.0 \%)$ had six to ten years of experience in processing while $(2.3 \%)$ of the respondents still stay till twenty-one to twenty-five in the study area. Results indicated that (54.0\%) of the respondents using improved processing technologies (modern) in the study area. Also, the monthly income earned by the respondents in the study area range between \#20,100- \#40,000 per month, (34.1\%) had less than \#20,000 per month, (13.1\%) had income range between \#40,100$\# 60,000$ while $1.7 \%$ had between \#60,100-\#80,000 and only $(0.6 \%)$ of the respondents did not state their income per month. The implication is that respondents need to engage themselves in another income generating activities in order to increase their economic status, so as to acquire more improved processing technologies. This agreed with the finding of FAO (2001) that rural dwellers characterized with meager income. 
Table.1: Socio-economic characteristics of the respondents

Variable Frequency Percentage Mean

Age (years)

11-20

3

21-30

1.7

41.23

$31-40$

27

15.3

41-50

65

36.9

51-60

44

25.0

Above 60

28

15.9

Sex

Male

Female

133

24.4

Religion

Christian

107

75.6

Muslim

Tradition

64

60.8

36.4

2.8

Marital status

Single

16

9.1

Married

133

75.6

Divorce

Separated

Widowed

16

9.1

Educational background

No formal

Vocational education

Primary school

2

62

35.2

Secondary school

Tertiary school

12

Household size

1-3

23.3

4-6

7-9

$10-12$

No states

1

0.6

Year of experience

$\begin{array}{ll}1-5 & 5 \\ 6-10 & 58 \\ 11-15 & 31 \\ 16-20 & 31 \\ 21-25 & \end{array}$

$52 \quad 29.5$

$58 \quad 33.0$

$31 \quad 17.6$

$31 \quad 17.6$

$4 \quad 2.3$

Method of processing

Traditional

$37 \quad 21.0$

Modern

95

54.0

Traditional \& modern

44

25.0

Income earn (\#)

$<20,000$

60

34.1

20,100-40,000

89

50.6

$40,100-60,000$

23

13.1

$60,100-80,000$ 


Not stated 110.6

$\begin{array}{lll}\text { Total } & 176 & 100.0\end{array}$

Source: Field survey, 2017.

\section{Respondents' awareness on improved processing} technologies

By categorization of level of awareness in table $2 b$ showed that the level of awareness of improved processing technologies is low (54.5\%) and high (45.5\%) in the study area. The implication of this is that those who claimed to be awared got the information through educational background or exposure to social network. This is in line with Bamikole et al (2016) that reported that apart from grater, presser, fryer machines that have their awareness rate above $50 \%$ awareness rates of processing is low.

Table.2a: Respondents' awareness on Improved Processing Technologies

\begin{tabular}{llcccc}
\hline Improve d processing technologies & \multicolumn{2}{c}{ Aware } & \multicolumn{2}{c}{ Not Aware } \\
& & F & \% & F & \% \\
\hline 1. & Mechanical grater & 161 & 91.5 & 15 & 8.5 \\
2. & Screw Press hydraulic jack & 160 & 90.9 & 16 & 9.1 \\
3. & Motorized Peeler & 67 & 38.1 & 109 & 61.9 \\
4. & Granulator & 128 & 72.7 & 48 & 27.3 \\
5. & Kiln Dryer/Drum Dryer & 154 & 87.5 & 22 & 12.5 \\
6. & Improved Pulverized & 66 & 37.5 & 110 & 62.5 \\
7. & Sifter & 81 & 46.0 & 95 & 54.0 \\
8. & Aluminum Fermentation tank & 72 & 40.9 & 104 & 59.1 \\
9. & Hammer mill & 157 & 89.2 & 19 & 10.8 \\
10. Washing Machine & 81 & 46.0 & 95 & 54.0 \\
11. Dewatering & 123 & 69.9 & 53 & 30.1 \\
12. & Rotating Sieve & 121 & 68.8 & 55 & 31.3 \\
\hline
\end{tabular}

Source: Field survey, 2017.

Table.2b: Level of awareness

\begin{tabular}{clrllll}
\hline Category & f & \% & Mean & SD & Minimum & Maximum \\
\hline Low & 96 & 54.5 & 7.76 & 3.62 & 0.00 & 12.00 \\
High & 80 & 45.5 & & & & \\
\hline
\end{tabular}

Source: Field survey, 2017.

Respondents' attitude on the improved processing technologies.

Table $3 b$ revealed that $(56.8 \%)$ of the respondents had positive attitude to utilize improved processing technologies while $(43.2 \%)$ had positive attitude towards utilization of improved processing technologies. Also table 3a showed that $(69.9 \%, 66.5 \%$ and $58.0 \%)$ agreed strongly to modern cassava processing method increase production, modern processing save time and also ready to recommend the techniques to their friends respectively. The implication is that the respondents may eager to utilize the improved processing technologies due to the benefits cum the improvement of their standard of livings.

Table.3a: Respondents Attitude on the improved Processing Technologies $(N=176)$

\begin{tabular}{llllll}
\hline Attitudinal Statement & SA & A & D & SD & Mean \\
\hline Modern cassava processing method save time & 117 & 46 & 12 & 1 & 3.52 \\
& & $(66.5)$ & $(26.1)$ & $(6.8)$ & $(0.6)$ \\
Spare parts of improved methods are not readily & 4 & 35 & 81 & 56 & 1.77 \\
available & & $(2.3)$ & $(19.9)$ & $(46.0)$ & $(31.8)$ \\
\hline
\end{tabular}




\begin{tabular}{|c|c|c|c|c|c|}
\hline Modern cassava processing method increase production & $\begin{array}{l}123 \\
(69.9)\end{array}$ & $\begin{array}{l}40 \\
(22.7)\end{array}$ & $\begin{array}{l}13 \\
(7.4)\end{array}$ & 0 & 3.55 \\
\hline $\begin{array}{l}\text { Fund is not a problem to acquire the improved } \\
\text { techniques }\end{array}$ & $\begin{array}{l}14 \\
(8.0)\end{array}$ & $\begin{array}{l}7 \\
(4.0)\end{array}$ & $\begin{array}{l}19 \\
(13.6)\end{array}$ & $\begin{array}{l}131 \\
(74.4)\end{array}$ & 2.06 \\
\hline In operation of modern techniques injuries are sustained & $\begin{array}{l}44 \\
(25.0)\end{array}$ & $\begin{array}{l}109 \\
(69.9)\end{array}$ & $\begin{array}{l}19 \\
(10.8)\end{array}$ & $\begin{array}{l}4 \\
(2.3)\end{array}$ & 3.01 \\
\hline I'm not feeling comfortable using the method & $\begin{array}{l}8 \\
(4.5)\end{array}$ & $\begin{array}{l}10 \\
(5.7)\end{array}$ & $\begin{array}{l}73 \\
(41.3)\end{array}$ & $\begin{array}{l}85 \\
(48.3)\end{array}$ & 1.73 \\
\hline $\begin{array}{l}\text { Instability of electricity prevents the use of improved } \\
\text { method }\end{array}$ & $\begin{array}{l}16 \\
(9.1)\end{array}$ & $\begin{array}{l}17 \\
(9.7)\end{array}$ & $\begin{array}{l}42 \\
(23.9)\end{array}$ & $\begin{array}{l}101 \\
(57.4)\end{array}$ & 2.04 \\
\hline Use of modern method reduces the use of hired labour & $\begin{array}{l}14 \\
(8.0)\end{array}$ & $\begin{array}{l}34 \\
(19.3)\end{array}$ & $\begin{array}{l}121 \\
(68.8)\end{array}$ & $\begin{array}{l}7 \\
(4.0)\end{array}$ & 1.67 \\
\hline $\begin{array}{l}\text { I will recommend modern methods of cassava } \\
\text { processing to any friend }\end{array}$ & $\begin{array}{l}102 \\
(58.0)\end{array}$ & $\begin{array}{l}51 \\
(29.0)\end{array}$ & $\begin{array}{l}21 \\
(11.9)\end{array}$ & $\begin{array}{l}2 \\
(1.1)\end{array}$ & 3.33 \\
\hline $\begin{array}{l}\text { I prefer used of hand grating as traditional method } \\
\text { techniques }\end{array}$ & $\begin{array}{l}29 \\
(16.5)\end{array}$ & $\begin{array}{l}23 \\
(13.1)\end{array}$ & $\begin{array}{l}92 \\
(52.3)\end{array}$ & $\begin{array}{l}32 \\
(18.2)\end{array}$ & 1.94 \\
\hline Stone pressing as traditional techniques is cheaper & $\begin{array}{l}125 \\
(71.0)\end{array}$ & $\begin{array}{l}38 \\
(21.6)\end{array}$ & $\begin{array}{l}11 \\
(6.3)\end{array}$ & $\begin{array}{l}2 \\
(1.1)\end{array}$ & 3.57 \\
\hline
\end{tabular}

Source: Field survey, 2017.

Table 3b: Categorization of respondents by their attitude

\begin{tabular}{lllllll}
\hline Category & F & \% & Mean & SD & Minimum & Maximum \\
\hline Unfavorable & 76 & 43.2 & 28.20 & 5.03 & 11.00 & 41.00 \\
Favorable & 100 & 56.8 & & & & \\
\hline
\end{tabular}

Source: Field survey, 2017.

Hypothesis: test of relationship between awareness of the respondents and their utilization of improved processing technologies.

This hypothesis was tested with the aid of PPMC. The result of the analysis in Table 4 revealed that there is a significant positive relationship between awareness $(\mathrm{r}=0.524, \mathrm{P}=0.000)$ of the respondents and their utilization of improved processing technologies This implies that the more the respondents aware of improved processing technologies, the more they will utilize it.

Table 4: Pearson Product Moment Correlation (PPMC) analysis between Awareness of improved processing technologies and their utilization

\begin{tabular}{lccc}
\hline Variable & $\mathrm{r}$ & $\mathrm{p}$ & Decision \\
\hline Awareness & 0.524 & 0.000 & Significant \\
\hline$* *$ Correlation is significant at the 0.01 level (2- tailed)
\end{tabular}

\section{CONCLUSION AND RECOMMENDATIONS}

More females than males that married with secondary education alternative involves in cassava processing in the study area. Awareness of the respondents of improved processing technologies was low.

The study thus, concludes that

Based on the empirical findings of this study, the following recommendations are made;

Government should create or build factory or industry where improved processing technologies would be fabricated at low cost. Also fund Research adequately and have MOU (Partners) with private Organizations to come up with quality/ standard improved processing technologies for increased productivity. Workshops and seminars should be periodically organized through extension by the government and NGOs for cassava processors on effective use of improved processing technologies. This will go a long way in easing effective use of improved processing technologies. 


\section{REFERENCES}

[1] Adedeji, T.O., Nosiru, M.O., Akinsulu, A.A., Ewebiyi, I.O., Abiona, B.G. and Jimoh, T.S. 2013. Adoption of New Rice for African (NERICA) technology in Ogun State, Nigeria.Journal of Development and Agricultural Economic. 5(9): 365-371. Sept. 2013.

[2] Akinbile, L. 2007. Social impact of limestone exploitation in Yewa North Local Government of Ogun State.Pakistan journal of social science. 1:107111

[3] Ewebiyi, I.O. and Arimi, K. 2013. Gender differentials in adoption of improved cassava production Technology in Ogun State.Journal of Agricultural Science and Policy research Vol.3 (2) 1-10.

[4] Oluwatayo, I.B. and Aliyu, A.A. 2007. Gender differentials in Information Communication Technologies (ICTs) Usage in Rural Nigeria: Case of Atis bo Local Government Area of Oyo State. Nigerian Journal of Rural Sociology. 7.1\&2:64.

[5] Torimori, D.O., Kolawole, O.D and Adeogun, M.O. 2006. Nigeria's University based rural Development Project: an exemplary holistic model for rural communities empowerment in sub-saharan African region. Nigeria journal of rural sociology. 6.1\&2:7-8. 